with deep grief and bitter anger that her special day had been ruined. In some ways it was a sweet release: "We were war weary. It had been a long battle. Someone had to break the vicious circle." A month after Jennifer's funeral, June asked Wallace whether a banner could be floated across the skies of Haverfordwest. When asked what it would say, she replied: "June is alive and well and has at last come into her own."

The vividness and power of these extracts makes you wonder why there are not more contemporary examples of twins talking about themselves. The book could perhaps have quoted from How Twins Grow Up by Mary Rosambeau; not literary maybe, but certainly real and immediate.

Farmer's book is a rich and strange slice of the literary cake. Twins themselves and ideas about twins are seen from every perspective and by every kind of writer: from St Augustine to Kurt Vonnegut; from Galton to Graves; from Shelley to Poe. There are twins as variations on the same person; twins as two different people; twins in myths, and myths about twins; and twins as the pivot on which every kind of literary plot turns. For most people, perhaps there is more about twins than they want to know. For those of us who have twins of our own, it's great.

John Galloway is at the Eastman Dental Institute, 256 Gray's Inn Road, London WC1X 8LD, UK.

\section{Brown fables, green wit}

\section{Stuart Pimm}

Betrayal of Science and Reason. By Paul R. Ehrlich and Anne H. Ehrlich. Island Press:1996. Pp. 320. \$24.95.

THE Ehrlichs have been insulted, their sanity questioned, their writings and depressingly accurate apocalyptic predictions misquoted, their humanity denied, and their friends likewise besmirched. Like the Ehrlichs themselves, this is a wickedly funny book and it takes no prisoners among their critics. Panglossian critics of the Ehrlichs are skewered with their own words and simple, choice responses. For good measure, the book addresses why so much of the scientific opinion is so readily represented to the public as "the hysterics of a few pseudoscientists".

The core chapters are about fables. Paul Ehrlich attained notoriety with The Population Bomb (Amereon, New York), so fables of food and famine, disease and death appropriately come first. Julian Simon claims we have "the technology to feed an ever-growing population for the next 7 billion years"; Malcolm Forbes that population growth in the United States "is not a problem because it's still nowhere near as dense as the Netherlands"; Dixy Lee Ray that the human population has not exploded; and others claim that medicine has eliminated infectious diseases, and famines are now only history. The pithy response to Simon is that if the population grew at only a millionth of its current rate, its mass would exceed that of the Universe well before the allotted time; presumably, the population would have to travel outwards faster than the speed of light to occupy the space.

Our population has expanded with clockwork precision from 3.5 billion when Ehrlich wrote his 1968 bestseller to almost exactly the 5.65 billion he predicted then for 1995. Assertions of the elimination of infectious diseases will hardly comfort the millions of children who die annually of gastro-intestinal infections, or adults who are now HIVpositive. "Emergent diseases" emerge, of course, because a disease may spread through a dense population but fizzle in a sparse one. Now, more than ever, we are abundant, concentrated in cities, and travel widely and rapidly, spreading diseases more efficiently.

What of the famous prediction that "hundreds of millions of people are going to starve to death... in the 1970s"? The Ehrlichs are delighted to report that they were wrong. Global programmes to improve food distribution reduced the decade's total deaths to between 100 million and 140 million, plus another 100 million since. Looking at these numbers, one wonders what authors like Michael Fumento (Science Under Siege; William Morrow, New York) could have been thinking in asserting that "none of [the Ehrlichs'] predictions ever come true", and that they were "off, by hundreds of millions".

The future will be much better, of course: The Economist (12 August 1995) tells us so. "Unimagined scientific breakthroughs will boost crop yields." The Ehrlichs ponder why this respected publication had not posited equally "unimagined breakthroughs (that) will allow a runner to run a two-minute mile". With more people, there will be more geniuses to solve our problems. Surprisingly, they seem to be in short supply in the former Yugoslavia and central Africa, where people are numerous, productive land scarce, and the problems deadly.

Fables about physical resources, economics, toxic substances and species extinction follow. English readers of Nature will be reassured that exposure to dioxin is no more dangerous than the week of sun and sand to which they look forward in the dark, damp days of February. Just don't count on global warming to improve the weather. Another fable; how could it be otherwise? As Gregg Easterbrook asks in A Moment on the Earth (Viking, New York), "since $\mathrm{CO}_{2}$ is only $1 \%$ of the atmosphere, why should we care if its concentration doubles?".

The ozone myths are more interesting. Volcanoes spew out large amounts of chlorine, and whether they or chlorofluorocarbons (CFCs) are the principal cause of the ozone hole is a legitimate scientific question. As it turns out, volcanic chlorine is mostly $\mathrm{HCl}$, and so is soluble in rain, whereas CFCs are insoluble and reach the stratosphere. This distinction between chlorine compounds is lost on the American talk-show host Rush Limbaugh, who continues to deny mankind's culpability. One can only hope that he learns to distinguish $\mathrm{NaCl}$ from $\mathrm{HCl}$, lest his millions of loyal fans lose their only source of science news.

The Ehrlichs stress how extensive is excellent reporting of science and its debates. Capable reporters do not feel compelled, for the sake of 'balance', to report the views of flat-earthers every time NASA publishes a photograph of Earth from space. Few have been in the glare of the media for as long as the Ehrlichs, whose recommendations on how to work with the media are short and useful. Those who can, should, presenting their conclusions first, avoiding stories of future scenarios, and carefully separating what actions are ideal and what are practical.

To distinguish good and bad science reporting, there is a simple field-guide quality to writing that one can easily pass on to students. Is the publication adequately referenced, or are there large tracts of completely unsupported statements? Is it peer reviewed? Are the peers few or numerous? Are they truly peers? Where do they publish? Like being a world-class cricketer or concert pianist, it's hard to fake being a worldclass scientist. These questions reveal all but the rare, well-qualified contrarians. To evaluate their claims, are there international, consensus statements, as there are on population, biodiversity and climate change?

If some politicians cannot recognize these obvious distinctions, the good news is that some can, and they act accordingly. It is to two of these, the late Republican senator John Heinz and his wife, that the Ehrlichs dedicate their book.

Stuart L. Pimm is in the Department of Ecology and Evolutionary Biology, University of Tennessee, Knoxville, Tennessee 37996, USA. 